\title{
Practical Politics of Machiavellii and Kautilya
}

\author{
Dr. Shiv Balak Prasad \\ Professor and Former Head, University Department of Political Science, B.N. Mandal University, Laloo \\ Nagar, Madhepura, Bihar (India)
}

\begin{abstract}
Political thought is thought about the state, its structure, its nature and its purpose. Really its concern is with nothing less than "-the moral phenomena of human behavior in society"-. There is practically no limit to what statesman can do, provided he understands the rules of his art. He can tear down old states and build new ones, changes forms of governments, transplant populations, and build new virtues into the characters of his subjects. If a ruler lacks soldiers, he need blame no one but himself, for he should have adopted measures to correct the cowardice and efficiency of his people. The law-giver is the architect not only of the state but of society as well, with all its moral-religious and economics institutions.
\end{abstract}

Keywords: Machiavelli, Kautilya, Political, Prince, Religion, Morality.

\section{INTRODUCTION}

Nicollo Machiavelli (1469-1527) occupies a unique place in the history of political thought. The value of his writings and contribution to political science may, even his motives and character has been variously assessed by successive students of politics and statecraft. To some Machiavelli was worse than unmoral; his motive in writing the Prince was to ideologize Caesar Borgia (1476-1507), the son of Pope Alexander VI, who was born of an unmarried wife of the Pope, Caesar Borgia had usurped power by getting his elder brother done to death, and had adopted cunning and dishonesty in realizing "Machiavelli's highest ideals of a superb and successful prince."1 H. G Wells estimates Machiavelli as a person who "manifestly had no belief in a God ruling over the world or in a God in men's hearts, no understanding of the power of conscience in men. It seemed to him that to get power, to gratify one's desires and sensibilities and hates, to swagger triumphantly in the world, must be the crown of human desire. His ruling thought, his great contribution to political literature, was that the moral obligations upon ordinary men cannot bind princes".2 Wells calls him a morally blind man who was living in a little world of morally blind men. It is true that most of the European Courts of that time were full of Secretaries who were evil geniuses of their sovereigns, and some of them, like Cromwell, the minister of Henry VIII of England, considered Machiavelli's Prince as "the quintessence of wisdom". Throughout Europe and more particularly in Italy, there were produced a number of monsters of evil.

It was undoubtedly an age in which everything was illegitimate and everything legitimate. Personality was free to expand itself to its natural limits. Extreme and glaring contrasts were the natural result. Against the brutalities of a Burnabo or a Giovanin Mara Visconti, the poisonings, wholesale murders and incests of the Borgias etc., might be set the saintly gentleness of St. Catherine of Siena, and the many-sided accomplishments of a Victorino da Feltre. That age was unmoral rather than immoral, concerning itself with what is rather than what should be. And Machiavelli was a true specimen of this age.

There are also persons who admire Machiavelli for his monstrosity of plain-speaking, his patriotism, and his ambition to see Italy unified and rose to the level of other rising monarchies in her neighborhood, and for his suggesting practical schemes which, however much they might be condemned on ethical or religious grounds, have largely been followed, during these four centuries and a quarter. They attribute to him noble intentions behind his political views. These contradictory estimates of Machiavelli have been responsible for giving so great a prominence to the thinker who, while presenting his age not merely in its broad contours but the minute details of the currents and cross-currents, has set successive generations of students of politics thinking whether practical politics can be really divorced from religion or ethics. And it is due to his frank admission of the necessity of 
adopting any means by the Prince, so long as these means serve his purpose, that anything which smells of cunning and craft is called Machiavellian.

Machiavelli has often been compared to Vishnu Gupta, better known by his popular name Kautilya or Chanakya, who flourished in the Indian kingdom of Magadha about eighteen centuries before the birth of the brilliant Florentine. Machiavelli is, for the reasons of some of his views resembling those of Chanakya, called the European Chanakya.

A critical comparative study of the writings and views of these two thinkers, Kautilya and Machiavelli, reveals interesting similarities, and yet they widely differ from each other in several important respects.

\section{The CharaCter OF THE TwO THINKERS}

Both Kautilya and Machiavelli represented their ages in a true setting. Kautilya had become the chief adviser of Chandra Gupta Maurya whom he had placed on the throne of Magadh after ending the rule of the Nanda dynasty. He was a brilliant scholar and a true virgin, endowed with marvelous gifts of organization and a keen insight into men's character. For a long time, he was looked upon as one of the greatest authorities on the sciences of government, and a long succession of writers on government have largely borrowed their views from him. He wrote his Arthashastra while he practically guided the destinies of Magadh, for the benefit of his king. The Arthashastra comprises six thousand Shlokas, dealing with the various aspects of government, beginning with the duties and the daily life of a king to the minutest details of the administrative machinery and the problems of sovereignty, the methods of warfare, the means to deal with neighbouring states, the different political institutions, system of taxation, local government, and the system of judicial administration. It is an undisputed fact, supported by overwhelming evidence, that most of Kautilya's views had been put into practice in the administration of Magadh.

Machiavelli's famous works, The Discourses and The Prince, were written after he had been deprived of all power in the Republic of Florence and had been compelled to live in virtual banishment. He had hoped thereby to win the favor of some aspiring prince and thus regain the position of being the righthand man of a ruler, a position he had held under the life president of Florence. No doubt before his expulsion from this position Machiavelli was for eighteen years in the diplomatic service of the Republic and was sent on several important missions. As such, he had acquired considerable knowledge of men and affairs and an insight into the intrigues of courts and embassies. He had hoped that by presenting The Prince to Lorenzo Di Piero de Medici, he would win the latter's favor, for he says, in the opening words of presentation, "I have not found among my possessions anything which I hold more dear than, or value so much as, the knowledge of the actions of men, acquired by long experience in contemporary affairs, and a continual study of antiquity; which, having reflected upon it with great and prolonged diligence, I now send, digested into a little volume, to your Magnificence." But Machiavelli did not achieve the favor he had hoped for; his work, however, supplied later writers on Political Philosophy with valuable ideas about practical politics.

\section{Their MeThOd of APPRoACh TO The Problem}

Both thinkers have relied on history and have frequently quoted from previous rulers. Their object was to suggest practical solutions to political problems as they found them. They had no taste for idealism or speculative thinking. They deal with men and affairs as they are and not as they might be. Both separate ethics from politics. But they differ in their views regarding religions and morality in life. Acharya Vishnu Gupta respects religion, values morality in rulers and state officials, as essential qualities. Machiavelli, on the other hand, divorces religion from politics to the extent of almost completely disregarding the value of religious principles and dogmas or moral values. Vishnu Gupta is not merely a practical politician but also a political scientist and theories on political philosophy by laying down definite principles. Machiavelli, the product of the intriguing atmosphere of European courts of the Middle Ages, has no concern with philosophizing and is, therefore, only a practical politician. This difference is due to the Magadhan having been a great scholar of Vedic culture prior to his coming into the field of politics, whereas Machiavelli had no such achievements to his credit. But both show considerable literary qualities in their writings and expressions. They adopted the methods, essentially the same, which they thought best for tackling the problems which were facing their states in their time. 


\section{THEIR VIEWS ON MORALITY AND RELIGION}

It is untrue to say that Vishnu Gupta had the same dislike or disregard for ethical principles and moral values as the Florentine. According to the former, the object of life is the attainment of Trivarga, viz., Artha, Dharma, and Kam, from the attainment of which the fourth object, namely, Moksha or salvation results. And of the Trivarga, he values Artha most because he thinks, without it, the other two cannot be achieved. And he definitely states that man cannot live happily in society unless he allows others similar happiness, and for this state of existence he prescribes a high standard of moral life, a control of senses and a respect for ethical principles. Thus Vishnu Gupta displays a fine synthesis of altruism, rationalism and moral principles. On the other hand, Machiavelli has no place for morality or religion apart from an outward show off these in order to impress those who value them. He says; "Therefore it is unnecessary for a prince to have all the good qualities I have enumerated,' but it is very necessary to appear to have them. And I shall dare to say this also, that to have them and always to observe them is injurious, and to appear to have them is useful; to appear merciful, faithful, humane, religious, upright, and to be so, but with a mind so framed that should you require not to be so, you may be able and know to change to the opposite".4 This is a shameless recognition of the necessity of hypocrisy, a parallel of which cannot be sighted in Kautilya's works. True, Kautilya suggests crooked ways of dealing with some of the problems of state, and his name Kautilya itself means 'crookedness', but he never permits bad faith or immoral conduct in the ruler. While Kautilya has faith in rigid discipline and control of senses, in the virtues of liberality and good faith: Machiavelli clearly says, "If men were entirely good this precept (namely of breach of faith) would not hold, but because they are bad, and will not keep faith with you, you too are not bound to observe it with them. Nor will there ever be wanting to a prince legitimate reasons to excuse this nonobservance."' He advises the prince not to fear the reputation of being mean, but Kautilya holds just the contrary views. The latter speaks of liberality and charity, as well as the reputation of being just, honest and truthful as essential qualities for a strong ruler.

\section{Their Views Regarding State AND GovernMENT}

Both Kautilya and Machiavelli hold almost similar views regarding the conception of the state. Both belief in the strong monarchy as the best form of government. Both attach importance to force and its use in keeping order and hence the necessity of a powerful king as head of the state. The law of punishment must remain ever vigilant to prevent the people of the four castes and orders from swerving from their respective duties and avocations. He looked upon Royalty as the most vital factor in the body-politics.

It must, however, be remembered that his ideals of Royalty was truly paternal in its attitude and working. The king must look upon the subjects as his own children. And "In the happiness of his subjects lies his happiness: in their welfare, but whatever pleases his subjects he shall consider as good."

Machiavelli also emphasizes the need of keeping the subjects contented, but not so much for any moral reasons as for the sake of retaining the prince's power. And that is why he warns the prince against depriving his subjects of their property and wealth, for such forfeitures are likely to cause hatred against him and ultimately frustrate his authority, and this he must avoid. In this connection, it is noteworthy to mark Machiavelli's indifference, not hostility, to morality.

Machiavelli, in the Discourses, gives his own view of the republic, city-state only, but is unwilling to believe that the rule of an aristocracy is any good. In his words: "The only way to establish any kind of order is to found a monarchical government; for where the body of the people is so thoroughly corrupt that the laws are powerless for restraint, it becomes necessary to establish some superior power which, with a royal hand, and with full and absolute powers, may put a curb upon the excessive ambition and corruption of the powerful".6

Both Kautilya and Machiavelli have prescribed the institution of a Council of Ministers as an extremely necessary adjunct to monarchical rule, and have gone into details regarding the qualifications of persons who should be appointed ministers. But as is evident in all parts of their writings, Kautilya shows greater insight into the conduct of men and pays greater respect to moral and religious attainments of the ministers than the Florentine. Machiavelli, absolutely indifferent to religion and the need of positive cultivation of morality whether in the prince or his subjects, has no need for a priest, but Kautilya considers the Priest (Purohita) to be the first and the foremost officer in 
the court. "Him whose family and character are highly spoken of, who is well educated in the Vedas and the six Angas, is skilful in reading portents, providential or accidental is well versed in the science of government, and who is obedient and who can prevent calamities, providential or human, by performing such expiatory rites as are prescribed in the Atharvaveda, the king shall employ as high priest. As a student his teacher, a son his father, and a servant his master, the king shall follow him".7 Both thinkers warn against the employment of weaklings or cowards or flatterers as ministers of the king.

Both emphasize the need for a strong and powerful army in a prosperous state. Both hate the idea of keeping mercenaries or discontented soldiers. Kautilya goes into greater details about the classification of armies and soldiers and how to deal with each arm than Machiavelli. The latter advises that a wise prince should not deem that "a real victory which is gained with the arms of others," whether auxiliaries or mercenaries and must turn to his own arms.8

\section{CONClusion}

It is difficult, within the short compass of this paper, to do even bare, to say nothing of adequate, justice to the two thinkers who exercised a profound influence on the political thought of their respective contingents, by analyzing and comparing their views in details. Machiavelli has been hailed by a chorus of the voice of European students of political science as the first of the long series of modern European political thinkers and as marking the dawn of modernism in European political philosophy. That Machiavelli was intensely patriotic and wanted Italy to take her rightful place in the circle of rising

European nations cannot be doubted. He laid the foundations of aggressive nationalism which has echoed through these four centuries in Europe and produced admirable aggressors like Mussolini and Hitler or Imperialists like Churchill. His chief object in writing The Prince and the Discourses was to show the practical way for the unification and strengthening of Italy on which he had set his heart. So long as the end was achieved, he cared little for the means adopted. His suggested remedy was definitely for Italy as he had found her. But it must be admitted that in all the subsequent political history of Europe, even up to the present Political Phenomenon, practical politicians have actually adopted what is maligned as Machiavellism, even though they were professing to be idealistic and moral, praying all the time to God, yet concealing a dagger up their sleeves. The utter disregard for the canons of international law and the consequent rape of neutrals even in the present war are examples of Machiavellism in Excelsis. Judged from the point of view of practical realism. Machiavelli has been adorned, in action, by politicians all over Europe.

Acharya Vishnu Gupta or Kautilya has laid posterity under a deep debt by giving a scientific treatise on the science (theory as well as practice) of government. Unlike Machiavelli, Kautilya never divorced politics from ethics. He values high moral principles and religious tenets as of supreme importance, and yet is intensely practical. Because the observance of the ordinance of religion is the cause of the greatness of commonwealth: so also is their neglect the cause of their ruin. True to ancient Hindu culture in which he had received highest education during the period of Brahmacharya, Kautilya never placed means above the end. His work served as an authoritative guide from which a long line of successive writers on politics has drawn freely to interpret Hindu view of the state.

Vishnu Gupta did prescribe crooked methods, but certainly not unmoral means, to discover the weak spots in the administration. Unlike Machiavelli, he finds many good qualities in human nature and strongly urges their cultivation and development. His writings carry the individual to a much higher plane than those of Machiavelli. He was a much greater scholar, almost an intellectual giant who raises high above a galaxy of scholars of Medieval or Modern Europe, than the Florentine who looks like a dwarf compared with the Magadhian.

Ever since the Greek contact with India, more than three centuries before the Christian era, Indian literature had been imported into Greece and the neighboring countries. Hindu thought had considerably influenced European thought, and it is not outside the range of possibility that Machiavelli clearly shows that the latter has given as nothing which had not already been given us by Kautilya more than eighteen hundred years before the Florentine. The credit of originality goes to Kautilya, and Machiavelli, for that reason, owes a great debt to him for all that he has written, barring, of course, the indifference to religion and morality. 


\section{REFERENCES}

[1] H.G. Wells - The Outline of History, P. 781.

[2] Ibid. PP. 781-82.

[3] Nicclo J. Machiavelli: The Prince (Ed) Adolpucaso, Rules Goodwill (Translator), Benjamin Martinaz (Illustrator, Published 1513-1429 edutains 0, 203.

[4] The Prince, (Every Man's Library ed.), p. 143.

[5] Ibid. p. 142.

[6] Discourses, P. 1, 55.

[7] The Arthashastra, Perguin Books India Pvt. Ltd, New Delhi 1992, P. 15.

[8] The Prince, pp. 108-109 rivifia-cz 2-57. 